\title{
Sex and Gender in Family Business Succession Research: A Review and Forward Agenda From a Social Construction Perspective
}

Family Business Review

I-23

(C) The Author(s) 2017 Reprints and permissions: sagepub.com/journalsPermissions.nav DOI: I0.1 I77/08944865।77/5390 journals.sagepub.com/home/fbr (S)AGE

\author{
Teresa Nelson' and Christina Constantinidis ${ }^{2}$
}

\begin{abstract}
This article focuses on how family business succession research has engaged and may be further enriched by application of a gender lens as socially constructed. We analyze the succession literature developing a gender terms vocabulary and five themes of historical engagement. Finding a lack of theoretical grounding, we apply the construct of gender, through expectation states theory, revising the Sharma and Irving model of successor commitment to examine how a socially constructed view of gender shifts and opens up points of view. We then present a forward looking agenda to motivate future scholarship.
\end{abstract}

\section{Keywords}

family business succession, social construction, primogeniture, gender, Sharma and Irving model of successor commitment

\section{Introduction}

This article focuses on how family business succession research has engaged and may be enriched by application of a gender lens as socially constructed. We study 21 years of family business succession research to determine how the concepts of sex (the biological category of female and male) ${ }^{1}$ and gender (a social construct that establishes expectations of what men and women are and what they can and should do) have been used and theorized. Finding a significant gap in theoretical development, we propose that gender can be applied to enrich existing models of succession, as illustrated here through application of expectation states theory (Ridgeway, 2011) to the Sharma and Irving (2005) model of successor commitment. Furthermore, we motivate the use of gender as a construct for knowledge building on succession by presenting a set of ready-to-be-explored research questions across levels of analysis that address gender vis-à-vis succession states, processes, participants, outcomes, and context. Finally, we provide links to gender theory for researchers interested in extending this work.
This work is important because family business continues as a dominant organizational form globally (for an overview, see Daspit, Holt, Chrisman, \& Long, 2015; Nordqvist, Wennberg, \& Hellerstedt, 2013) and because, at the heart of it, families are made up of female and male. The interpersonal relationships of parents to children, siblings to each other, parents to each other, and so on, all carry gender implications that play out in the dynamics of business succession for the business and the family (even if all family members are one sex or another).

Increasingly, worldwide, these family relationships are embedded in contexts where a monolithic expectation of primogeniture (the normative assumption of the eldest son assuming family business control in the next generation) is being challenged and questioned. Systemic political and cultural forces, for example, China's now

\footnotetext{
'Simmons College, Boston, MA, USA

${ }^{2}$ University of Luxembourg, Luxembourg

Corresponding Author:

Teresa Nelson, Simmons College, 300 The Fenway, Boston, MA 02215, USA.

Email: teresa.nelson@simmons.edu
} 
historic but still immensely influential one child policy, Islamic requirements regarding wealth transfer to women, and more generally, support for sex/gender equality principles are driving change in family business succession processes from the bottom-up and top-down. For example, following famous pioneering female successors such as the second- and third-generation leaders of Prada, Luisa, and her daughter Miuccia Bianchi Prada, the second-generation head of Carlson Companies Marilyn Carlson Nelson or the third-generation leader of the Galeries Lafayette French group Ginette Moulin, daughters are being widely, seriously considered (by themselves and their parents) as potential leadership successors in small and large businesses, in many families, around the world for the first time (e.g., House, Hanges, Javidan, Dorfman, \& Gupta, 2004; MassMutual Financial Group/Raymond Institute, 2003; Moore \& Gupta, 2007). Furthermore, changes in social relations within families and the structure of careers give children greater flexibility and a larger say in whether they will sign up with the family firm.

Understanding this dynamism takes on more meaning when we consider the peak wealth transfer to younger generations expected over the next 20 to 30 years in Western Europe and the United States (Accenture, 2015; European Commission, 2009; Kurzo \& Jaecklin, 2014). Predictions suggest that there will be family turnover in $68 \%$ of the world's Top 500 family businesses employing 21 million and contributing US\$6.5 trillion to global GDP (Bain, 2015) in the time period. Beyond the West, family businesses represent more than half of all large corporations across the AsiaPacific regions (Fernández-Aráoz, Iqbal, \& Ritter, 2015) and expectations of hand-down to heirs or close relatives stands at $75 \%$ of companies in China and Southeast Asia (Koh, Ling, Kong, \& Ejercito, 2015). In India, 50\% of surveyed companies are confident to pass on management to the next generation (PwC Family Business Survey, 2013). In the Middle East, outside of the oil sector, most of GDP and over $80 \%$ of businesses are familyrun or controlled (PwC Family Business Survey, 2012).

Who is considered, developed, and empowered to lead the family company for the next generation is an increasingly complex decision (Casillas, Acedo, \& Moreno, 2007; Le Breton-Miller, Miller, \& Steier, 2004) and sex and gender ideas are intrinsic to that complexity. We therefore define the following research questions for our work.
Research Question 1: With what meaning and to what degree does the family business succession literature historically consider gender and/or sex as a theoretical construct and variable of interest?

Research Question 2: How can a social construction of gender lens be conceptualized to add value to family business succession research moving forward?

There are four major sections of the article. First, we present an overview on the social construction of gender as an epistemological position. While social construction is increasingly used in business research, it is rarely explained: social construction is not a theory, per se, but a way of viewing the world; a paradigm of knowledge that contextualizes various theories and their meanings. (Later in the article, we use one theory developed within the social construction paradigm, expectation states theory, to explore gender in succession processes directly.)

In the second part, in reference to Research Question 1 , we examine 21 years of family business succession literature to see how sex and gender have been considered. We identify the gendered vocabulary employed in the research stream as well as five themes that typify how sex and gender have been used by researchers over the time period. From this work, we present four findings that set the frame and points of reference to consider future research.

In the third part, we move to a forward looking agenda. We use expectation states theory (Ridgeway, 2011) with a gender lens to examine a leading model of family business succession: the Sharma and Irving (2005) model of successor commitment. We revise the model with gender awareness and explain how a socially constructed view of gender changes its point of view as well as our understanding of the attitudes and behaviors of potential successors. This practically illustrates how gender can be used to revisit and revise existing scholarship either as a focal point of research or through the development of secondary but serviceable variables and/or contextual frames.

We also present a forward looking agenda for research on gender in family business succession within and across levels of analysis and across the stages of presuccession and succession. We share a series of unexplored research questions on gender and succession and also provide touchstones to additional gender theories that can be used to enrich succession knowledge. Our fundamental goal is to open a pathway for researchers to see 
the power of gender as a force and context of family business succession and to understand how to continue or begin to apply a gender lens in their work. In the last part, we consider our study overall, its meaning, and implications.

\section{Paradigmatic Lens: The Social Construction of Gender}

Human consideration of the question, "What is reality?" has kept philosophers and more pedestrian thinkers busy for millennia. With the intellectual architecture built by Durkheim, Marx, and Weber in the late 19th and early 20th century, the new discipline of sociology took hold of one part of the larger question by addressing social reality, the role of society on the perception of human reality. Very simply, we can acknowledge a thought legacy including Marx's (2010) assertion that a person's consciousness is determined by his or her social being. Durkheim $(1938,1951)$ illuminated the social influences on the condition and decisions of individuals, while Weber $(1978,2009)$ brought attention to the meaning of social action, and of the cultural norms, values, and symbols that transmit it. From the intellectual heritage of Weber came Schütz (1972), a founder of social phenomenology, or how things appear, that is, how the present moment is considered in daily life by everyday people. He saw social meaning as being constructed among individuals, created by them and by those who came before, thereby establishing an institutional thought environment. A legacy of Schütz was realized in the work of P. L. Berger and Luckmann (1966), who credited Schütz with the foundational ideas that led to their highly acclaimed scholarly book, The Social Construction of Reality: A Treatise on the Foundations of Knowledge.

In this book, P. L. Berger and Luckmann (1966) introduced the term and concept of social construction to a wide academic audience. Knowledge as applied here meant not a body of wisdom but rather a name for what we as everyday people know.

The theoretical formulation of reality, whether that be scientific or philosophical or even mythological, does not exhaust what is "real" for the members of a society. Since this is so, the sociology of knowledge must first of all concern itself with what people "know" as "reality" in their everyday, non- or pre-theoretical lives. (p. 15)
The intersection with institutional ideas comes as this reality is "taken for granted as reality. It does not require additional verification over and above its simple presence. It is simply there, as self-evident and compelling facticity" (P. L. Berger \& Luckmann, 1966, p. 23). As others are part of this simply there, I typify them. "Thus I apprehend the other as 'a man,' 'a European, ' 'a buyer,' 'a jovial type,' and so on" (P. L. Berger \& Luckmann, 1966, p. 31). These typifications combine to be what we call social structure and because they are continually refreshed, they allow social structure to persist. This world is intersubjective among people, created and enforced by language and habits, belief systems, and social norms (among other forces). Therefore, it can vary across time and across cultures. To counter this constructed social reality takes deep attention.

Philosopher Ian Hacking (1999, p. 7) tells us, "Undoubtedly the most influential social construction doctrines have had to do with gender." A legacy of feminist thought since de Beauvoir (1953) has worked to distinguish gender as a socially constructed concept from sex, a biologically determined state, and in so doing, to "make the case" for social equality of women and men to be realized in business practice, among other social spheres. Sociologists and gender scholars (e.g., Butler, 2006; Collins, 2008; Eagly, 2009; hooks, 2014; Ridgeway, 2011; Smith, 1987; etc.) integrated de Beauvoir's work on sex and gender within the paradigm of the phenomenological roots of Schütz's social construction to discuss how gender is done thus leading to the creation and exploration of a number of theories. For example, Smith (1987) and colleagues, including Harding (1993, 2010) and Hartsock (1997, 2004), developed standpoint theory ${ }^{2}$ to examine the gendering, and associated marginalization, of everyday individuals within a framework of the taken-for-granted conceptualizations built at the social collective level.

Within a social construction framework, assumptions and conditions of men and women that are seen to be causally or associatively related to gender inequality can be taken as not permanent or inevitable; they can be changed: they do change and they vary across cultures and time. This view of gender counters the linguistic practice of many in academia, business, media, and beyond who use gender and sex as synonyms and gender and gendering as a condition of women and their bodies (Ahl, 2004). 
The social construction of gender has been presented as a framing mechanism in a number of pieces of management scholarship over the past decades with essential works provided by Ely and Padavic (2007) and Calás, Smircich, and Bourne (2009). Ahl's (2006) work and Ahl and Nelson (2015), show the presence and effect of gender as socially constructed on academic work and national policy, respectively. Jennings and Brush (2013) in their Academy of Management Annals review suggest that the conversation on entrepreneurship as a gendered phenomenon within a social constructionist perspective may be the greatest achievement of the now quite extensive literature on female entrepreneurship.

One of the primary places where we can identify and capture the meaning of gender is in language or discourse. Discourse makes and shapes reality: it is productive, not just representational. It orders things (people, ideas, organizations, etc.), and values them, making some things possible, and other things impossible (Foucault, 1995, p. 26). The more people draw on the same discourse, whether knowingly or unknowingly, the more institutionalized it becomes. The study of discourse then (i.e., discourse analysis) is both a conceptual orientation and a methodological technique.

We believe the field of family business succession as a whole is ripe for a more philosophically engaged conversation on gender, sex, women, and men because the impact of these ideas is so substantial in practice, the topic is widely considered, and - as seen from the results of this research - consistently undertheorized to date. We find language an effective partner in this endeavor.

\section{A Literature Review: Gender and Family Business Succession}

\section{Method}

With the following method, we will explore with what meaning and to what degree the family business succession literature historically considers gender and/or sex as a theoretical construct and variable of interest.

The Database of Articles. We reviewed and analyzed the comprehensive set of articles on family business succession published over 21 years (1995-2015) in six leading journals of the domain: Family Business Review, Journal of Small Business Management, Entrepreneurship: Theory and Practice, Journal of Business Venturing, International Small Business Journal, and Small
Business Economics. We selected these publications because they are top-ranked and well-cited and therefore contribute to shape the way that family business succession is conceptualized and studied and because they offer $95 \%$ of articles on family business succession (Nordqvist et al., 2013).

To identify articles for our database, we conducted three bibliographical searches. First, we undertook a Boolean search in university library databases that contained the sample journals. We searched titles, abstracts, and keywords for different combinations of the following words (in their truncated versions to include their singular/plural, feminine/masculine forms): family business coupled with succession, successor, daughter, son, sibling, offspring, transfer, generation, and predecessor. In all cases of building our data, we deleted redundancies and spurious cases that used our words but with a different meaning (e.g., parent company).

Second, we reviewed the bibliographies of recent literature reviews in family business succession (Daspit et al., 2015; Nordqvist et al., 2013) to identify additional articles. Finally, we conducted a directed search article by article using the publishers' electronic archives for the years 2011 to 2015, to ensure that we had captured recent work and to verify our existing list. We excluded book reviews, introductions to special issues, teaching cases, and interviews. Our final database consists of 157 articles including 117 , or $75 \%$, empirical papers (quantitative or qualitative) and 40 conceptual articles (literature review and/or theory development). In terms of methodology, of the empirical papers, most are based in studies of North America (42\%) and Europe (36\%) and $24 \%$ use a case study approach.

Building Our Gender Terms Vocabulary. To investigate the use of sex and gender concepts in the succession literature, we built a Gender Terms Vocabulary based on the idea of language as a meaningful expression of reality in practice (Foucault, 1995). We used the Delphi Technique engaging seven established gender scholars with strong publication records in entrepreneurship and family business to originate, refine, and review the terms list. The Vocabulary contains direct gender words (sex and gender) as well as embedded gender words that relate to one particular sex-based role in the family business context (e.g., patriarch, brother) or to nouns and adjectives commonly used in narrative with sex and gender meaning (e.g., masculine, woman). The direct and embedded gender words classification took on 
meaning in our analysis as we realized how many articles used gender terms without directly identifying, defining, or discussing their gendered nature. The complete list of gender terms, their use in the literature, and their conceptual structuring as introduced in this Method section is given in Table 2 which is presented in the Results section.

Determining a Database Categorization for Levels of Engagement of Gender Theory, Concepts, and Vocabulary. We used NVIVO (version 10) to identify within the database of articles the use of gender terms within the Vocabulary and to provide counts of term use by article and in the aggregate (see Table 2). Then, we independently read the text employing gender terms across all articles considering meaning and narrative context. We developed preliminary thoughts about categories of articles related to their overall use of gender theory, gender ideas, and the direct and embedded gender terms employed. Then, using an inductive process, we came together and, over time, agreed to $100 \%$ on a categorization scheme that divided all the articles in the database into three sets that represented meaningful divisions relative to the use of gender concepts: (a) No level of engagement (b) Limited level of engagement, or (c) Significant level of engagement. These categories will be more fully described in the Results section.

Establishing Gender Themes. Once the categorization of the articles in the database was complete, the articles engaging gender concepts were read again by each author independently with the goal of determining a set of gender themes representative of the historical literature overall. We defined a gender theme as a narrative or discourse that held embodied, distinctive meaning of gender; that an association of social norms or expectations was presented and/or attached to a biological male/female idea or variable (Ely \& Padavic, 2007). Again then, using an inductive process, we developed and compared our preliminary lists of potential gender themes and reviewed and reconciled them, building a narrative description of each confirmed theme in the process. These gender themes are interrelated (all articles did concern family business succession after all) and yet we found and agreed on meaningful clusters around distinctive concepts that deserved recognition and analysis.

Finally, providing reliability regarding our classification of articles by level of engagement, once the gender themes had been established, we computed the number of gender themes per article and found that number to be 4 and 5 for the Limited engagement category and 2 and 3 for the Significant engagement category. This supported our set design in that articles in the latter category were found to employ a deeper, more focused gender lens.

\section{Results}

Our results are organized in three parts. First, we describe how the family business succession literature (1995-2015) engaged with gender as a theoretical concept. Second, we present the use of gender terms with a counts approach. Third, we share our analysis of five gender themes identified in the literature using a narrative discourse method.

Use of Gender as a Concept in the Literature Across Journals and Years. Nearly $80 \%$ of the articles on family business succession published in six top-ranked journals over the past 21 years do not include conceptual ideas of gender and they were assigned to our No level of engagement with gender category. Of these articles $(n=124), 11 \%$ do not use sex or gender terms at all, either direct or embedded. Indeed, $68 \%$ use words from the Gender Terms Vocabulary (direct or embedded), but their meaning from a gender perspective is not considered in any way. For instance, a variable of Male/Female may be used, or the word "gender" as a synonym for the word "sex" is employed to describe the children of the family business, that is, men and women, boys and girls, but the concepts underlying the words are not exploited.

Of the remaining $21 \%$ of articles in the database, $13 \%$ constitute the Limited level of engagement with gender category as they provide expression of gender concepts, however, slight, using direct and embedded gender terms, with some conceptual meaning used to motivate the argument or explain findings. The remaining $8 \%$ of database articles make-up the Significant level of engagement with gender category as they use a theory of gender and/or socially constructed ideas of gender, and/or a discourse of gender, to more extensively motivate the study, contribute to the theoretical argument, or explain findings. Without mentioning it explicitly, most articles in the Significant category use a liberal feminist stance, describing gender biases and structural barriers in different contexts, though primarily within the family and the family business (e.g., Dumas, 1998; Dumas, Dupuis, Richer, \& St-Cyr, 1995; Galiano 
\& Vinturella, 1995; Haberman \& Danes, 2007; Harveston, Davis, \& Lyden, 1997; Stavrou, 1999; Vera $\&$ Dean, 2005). Some articles refer to psychoanalytic approaches, highlighting specific leadership styles of women as a group (e.g., Galiano \& Vinturella, 1995; Haberman \& Danes, 2007; Harveston et al., 1997). Only Haberman and Danes (2007) mention that something other than male/femaleness, for example, knowledge, can be gendered.

Family Business Review delivered the preponderance of articles in all three categories over the 21-year period (57\% of total; $77 \%$ in the Significant category). Entrepreneurship: Theory and Practice took a distant second position and the other journals split the remaining articles, more or less (Table 1). Use of gender as a construct over time in the literature across the 6 journals has been light overall and especially since 2010 which, to 2015, offered only 3 articles at the Limited or Significant engagement level across 33 articles on family business succession. In addition, most new research in succession is in the No engagement-level category and articles with a Significant gender focus are skewed to the past (an average date of publication of 2001 with the most recent article being published in 2011). There is not much coverage of new ideas of gender in recent succession research (Table 1).

Gender Term Counts. In Table 2, we report counts of usage for elements of the Gender Terms Vocabulary across the three categories of database articles. In terms of direct gender terms (sex and gender), we note that "sex" is a little used term across all three categories $(n=$ 20 uses out of 5,889 direct and embedded gender terms over 157 articles). We find that authors substitute the term "gender" for "sex" as a matter of course, as though these terms are synonyms, though theoretically, we posit, they are not. Embedded gender terms were used much more extensively than direct gender terms ( $n=5,487$ vs. $n=402$ ), which indicates that gender concepts are more likely indirectly than directly addressed. The embedded gender terms "father" and "son"3 lead in being used in more than half of all database articles, whether they engage gender concepts or not, revealing a dominant male representation in the succession literature.

For the set of articles with gender engagement (the Limited and Significant categories together), we find gender terms included in the following percentage of articles: "son" (85\%), "daughter" (82\%), "father" (76\%), "brother" (64\%), "mother" (55\%), and "wife"
(55\%) opening up the discussion to consider women as well as family roles beyond the patriarch and son/s. Finally, we note that "masculinity" and "femininity", terms used extensively in the gender studies literature to connote gendered patterns of behavior, are little used in family business succession research. These constructs could be employed to explore how gender expectations fall on women and men around succession behaviors and attitudes.

Finally, for the Significant level of engagement category, unsurprisingly both gender direct and embedded terms are employed at a much higher rate (Table 2) and "daughter" ranks as the most frequently used vocabulary word $(n=327)$ and "woman" outnumbers "man" by more than 2 to $1(n=660$ to $n=315)$ : these articles focus mainly on women and their situation in comparison with their male counterparts.

Gender Themes in the Literature. We identified five themes emerging from the discourse of gender in articles making up the Limited and Significant database categories. An overview of the themes and their definitions are discussed and sample discourse fragments are provided in Table 3.

Theme 1, gender equality and equity attitudes in the family, involves family consideration of gender (in) equality (equivalent treatment) and gender (in)equity (fair treatment) in terms of women and men; sons and daughters. This theme concerns family reckoning (or not) with gender equality and equity standards in reference to family members, primarily of the senior generation for the junior. Gender inequality or inequity involves the assumption and/or practice of unequal division of authority and resources on the basis of sex, including ownership, leadership, and participation in the decisionmaking process. Topics include direct succession to the top leadership role, membership in the family business, for example, the role of spouses, and the increasing assumption of women as equals (or not) in family businesses. As the role of women changes, there is a shadow reference to the impact of this change on men, and a direct reference to their organizations, which must change as a result.

Theme 2, gender roles, refers to the common roles of activity found in business (leader, successor, owner, etc.) in terms of societal expectations about what men can and should do, and what women can and should do. This was the most common theme across the articles of the database. Gender roles refers to the part played by a 
Table I. Articles on Family Business Succession by Journal and by Level of Engagement of Gender Concepts, 1995-20I5.

\begin{tabular}{|c|c|c|c|c|}
\hline & $\begin{array}{l}\text { Family business } \\
\text { succession } \\
\text { articles }(n=157)\end{array}$ & $\begin{array}{c}\text { No engagement } \\
(n=124), \text { percentage } \\
\text { of articles }\end{array}$ & $\begin{array}{l}\text { Limited engagement } \\
(n=20), \text { percentage of } \\
\text { articles }\end{array}$ & $\begin{array}{c}\text { Significant engagement } \\
(n=13) \text {, percentage of } \\
\text { articles }\end{array}$ \\
\hline Family Business Review & $57 \%(90)$ & $52 \%(65)$ & $75 \%(15)$ & $77 \%(10)$ \\
\hline $\begin{array}{l}\text { Entrepreneurship: Theory } \\
\text { and Practice }\end{array}$ & $15 \%(24)$ & $15 \%(18)$ & $20 \%(4)$ & $15 \%(2)$ \\
\hline $\begin{array}{l}\text { International Small } \\
\text { Business Journal }\end{array}$ & $6 \%(10)$ & $7 \%(9)$ & $5 \%(I)$ & \\
\hline $\begin{array}{l}\text { Journal of Small Business } \\
\text { Management }\end{array}$ & $6 \%(10)$ & $7 \%(9)$ & & $8 \%(I)$ \\
\hline Small Business Economics & $7 \%(11)$ & $9 \%(I I)$ & & \\
\hline $\begin{array}{l}\text { Journal of Business } \\
\text { Venturing }\end{array}$ & $8 \%(12)$ & $10 \%(12)$ & & \\
\hline Total (\%) & 100 & 100 & 100 & 100 \\
\hline Most recent article & 2015 & 2015 & 2015 & 2011 \\
\hline Average publication date & 2005 & 2006 & 2003 & 2001 \\
\hline $\begin{array}{l}\text { Percentage of articles } \\
\text { since } 2010\end{array}$ & $31 \%(48)$ & $36 \%(45)$ & $10 \%(2)$ & $8 \%(1)$ \\
\hline
\end{tabular}

person as family business leader, employee, $\mathrm{CEO}$, predecessor, owner, and so on, in terms of what is considered possible and appropriate for them as men or women. Gender roles vary by context, over time, and by geography/culture, even as society values shift. Being a male leader in family business (apart from primogeniture which is its own theme) carries a normative assumption of power, responsibility, and participation in the business domain, and relatedly, in the family, when referenced. Some trace of consideration of how gender affects men is included. Females in dominant business roles are considered in reference to the male leadership norm: unusual, the other. The dominant subtheme in this category is the perceived negative impact of traditional gender roles on women (and daughters particularly) leading them to no or low positions in hierarchy, responsibility, and decision making; demand that wives fill the role of emotional caretakers and family buffers; the difficulties of females assuming roles in male-dominated contexts; and a lack of female role models. In juxtaposition, there is a persistent thread in the research discussing an increasing acceptance of women in family business leadership roles and in ownership.

Theme 3, gender identity, refers to how individuals define themselves as being a woman or man according to what it means to them to be a woman or man; how it influences their selves and their lives. We identify identity as an embedded concept used in the literature in three ways: how sons and daughters see themselves in reference to their families, particularly their parents (i.e., family identity); the age and life-cycle stages of family members (i.e., personal identity); and the identification of the family members with the family business (i.e., business identity). These three identity subthemes are interconnected and most of the articles that mention them, mention them together. How sons and daughters see themselves with regard to their families focuses most in the literature on the father-son relationship, sometimes characterized by some ambivalence. The identity of the father as family and business leader is systematically highlighted.

Theme 4, primogeniture as a succession process, recognizes the assumption and procedure within the business family of eldest male heir succession, as well as challenges to same, for instance, gender socialization for succession of girls. This theme contains the most contentious content, meaning that across the body of work, representing both the scholarship itself and the practices described, there is both a normative assumption of male primogeniture as well as a challenge to same. However, in none of the articles is primogeniture fully explored as a gendered condition of women and men and their family businesses; either it is an assumption of how things are done; a challenge to same, on behalf of women in the 
Table 2. Gender Terms Vocabulary and Counts of Use by Level of Engagement of Gender Concepts.

\begin{tabular}{|c|c|c|c|c|}
\hline & \multirow[b]{2}{*}{ Gender terms } & \multicolumn{3}{|c|}{ Level of engagement of gender } \\
\hline & & $\begin{array}{l}\text { No engagement, } \\
\text { No. of articles } \\
\text { (use count) }\end{array}$ & $\begin{array}{l}\text { Limited } \\
\text { engagement, No. of } \\
\text { articles (use count) }\end{array}$ & $\begin{array}{c}\text { Significant } \\
\text { engagement, No. of } \\
\text { articles (use count) }\end{array}$ \\
\hline \multirow{2}{*}{$\begin{array}{l}\text { Direct gender terms } \\
\text { category }\end{array}$} & Sex(es) & $3(7)$ & $6(11)$ & $2(2)$ \\
\hline & Gender(s) & $37(100)$ & $19(93)$ & $13(189)$ \\
\hline $\begin{array}{l}\text { Embedded gender terms } \\
\text { category }\end{array}$ & Total & $106(2,458)$ & $20(1,069)$ & $13(1,960)$ \\
\hline \multirow{36}{*}{$\begin{array}{l}\text { Embedded gender terms } \\
\text { breakdown }\end{array}$} & Sex-based family roles_-Head & & & \\
\hline & Patriarch(s)/patriarchal & $9(20)$ & $5(36)$ & $6(11)$ \\
\hline & Matriarch(s)/matriarchal & $3(3)$ & $\mathrm{I}(\mathrm{I0})$ & $\mathrm{I}(\mathrm{I})$ \\
\hline & Sex-based family roles & & & \\
\hline & Father(s) & $59(352)$ & $13(233)$ & $12(2 \mid 6)$ \\
\hline & Mother(s) & $25(126)$ & $10(37)$ & $8(108)$ \\
\hline & Husband(s) & $13(39)$ & $5(12)$ & $7(29)$ \\
\hline & Wife(ves) & $22(97)$ & II (43) & 7 (42) \\
\hline & Son(s) & $61(556)$ & $16(253)$ & $12(139)$ \\
\hline & Daughter(s) & $42(207)$ & $16(83)$ & II (327) \\
\hline & Brother(s) & $31(129)$ & $12(49)$ & $9(33)$ \\
\hline & Sister(s) & $20(44)$ & $10(25)$ & $5(9)$ \\
\hline & Father(s)-in-law & $2(2)$ & $0(0)$ & $0(0)$ \\
\hline & Son(s)-in-law & $10(13)$ & $4(4)$ & $6(11)$ \\
\hline & Brother(s)-in-law & I (2) & I (5) & $2(3)$ \\
\hline & Mother(s)-in-law & I (3) & $0(0)$ & $\mathrm{I}(\mathrm{I})$ \\
\hline & Daughter(s)-in-law & $5(\mathrm{II})$ & $\mathrm{I}(2)$ & $5(12)$ \\
\hline & Sister(s)-in-law & $2(2)$ & $0(0)$ & $\mathrm{I}(2)$ \\
\hline & Grandfather(s) & $6(20)$ & $2(2)$ & I (2) \\
\hline & Grandmother(s) & $0(0)$ & I (I) & I (I) \\
\hline & Grandson(s) & I (I) & $0(0)$ & $0(0)$ \\
\hline & Granddaughter(s) & $2(2)$ & I (I) & $0(0)$ \\
\hline & (Great-)Uncle(s) & II (44) & I (I) & I (I) \\
\hline & (Great-)Aunt(s) & $6(7)$ & I (I) & I (I) \\
\hline & Nephew(s) & $13(20)$ & $\mathrm{I}(\mathrm{I})$ & $0(0)$ \\
\hline & Niece(s) & $9(10)$ & I (I) & $0(0)$ \\
\hline & Sex-based successor & & & \\
\hline & Heir(s)—male and female & $49(296)$ & $9(25)$ & $6(22)$ \\
\hline & Heiress(es)—female only & I (I) & $0(0)$ & $0(0)$ \\
\hline & Sex-based nouns and adjectives & & & \\
\hline & Man(en)/male(s)/boy(s) & $57(174)$ & $16(91)$ & $12(3 \mid 5)$ \\
\hline & Woman(en)/female(s)/girl(s) & $51(262)$ & $16(151)$ & $12(660)$ \\
\hline & Masculin(e/ity) & $0(0)$ & $0(0)$ & $3(7)$ \\
\hline & Feminin(e/ity) & $2(2)$ & I (I) & $2(4)$ \\
\hline & Paternal(ist/ism) & $6(13)$ & I (I) & I (I) \\
\hline & Maternal(ist/ism) & $0(0)$ & $0(0)$ & I (2) \\
\hline
\end{tabular}

family; a concern in terms of selection of the most fit successor in terms of organization success and longevity; or a harm to family harmony. Overall, when it is discussed, primogeniture is presented as a tradition; some work considers whether successor choice based on competence over birth order is preferable. 
Table 3. Gender Themes Identified in the Literature Review.

Gender theme and description

Articles with significant engagement

I. Gender equality and equity attitudes in the family involves family consideration of gender (in)equality (equivalent treatment) and gender (in)equity (fair treatment) in terms of women and men; sons and daughters.

"Some respondents expressed misgivings about the principle of gender equality. One man, for example, commented: I still believe in the old adage that the man should lead the household. So, if you give a woman a large amount of money, sometimes it can (create) a rather subjugated relationship (at home)" (Gilding, 2000, p. 246).

“... Father decides on estate plan leaving the business to son and other assets to daughter; daughter has to accept any inequality, but son will get at least equal ..." (Dunn, 1999, p. 59).

"By this phase, a successor has been identified and the major task is to compensate children who are not going to be successors. Parents believe that it is important to be equitable with children, even though they recognize that they cannot treat all children equally" (Keating \& Little, 1997, p. 166).

"The successor accepted the position, although only in a symbolic capacity-decision making among the second-generation family members had become egalitarian" (Santiago, 2000, p. 23).

2. Gender roles refers to the common roles of activity found in business (leader, successor, owner, etc.) in terms of societal expectations about what men can and should do, and what women can and should do.

(Dumas, 1998; Dumas et al., 1995; Galiano \& Vinturella, 1995; Harveston et al., 1997; Matthews, Moore, \& Fialko, 1999; Mehrotra, Morck, Shim, \& Wiwattanakantang, 201 I; Poza \& Messer, 200I; Sharma \& Irving, 2005; Stavrou, 1999; Vera \& Dean, 2005)

“Growing up in a family business may well foster girls interest in entrepreneurial activities in general, however, as their parents' businesses represent more male-dominated types of industry (e.g., carpenter, electrician) these girls may seek fulfillment of their entrepreneurial career intentions by starting their own business in less male-dominated trades." (Schröder, SchmittRodermund, \& Arnaud, 20II, p. 3I5)

"As the son came to realize that his dream — the hands-on running of a growing business—would not be realized in the family firm, he also saw how trapped he was, both literally and developmentally. He and his wife resolved to postpone starting a family until he left the business, but he feared the strain of his leaving would cause a relapse in his father's health." (Dunn, 1999, p. 49)

"Male heirs have prerogatives over females, ... Elder brothers are likely to exercise the executive roles and younger brothers are likely to defer to their authority" (Yan \& Sorenson, 2006, p. 240).

"Some CEO spouses recognize that they are role models for the next generation and builders of new legacies, legacies their preceding generation did not consider important. One Senior Advisor-type CEO spouse in a third- to fourth generation business stated it this way: In a very male-oriented culture in the business, it's good if there are roles there for women to follow because of me"(Poza \& Messer, 200I, p. 32).

" ... The widow who becomes chairperson, the supportive wife who keeps the books, the behind- the-scenes 'chief emotional officer' are all stereotypical women's roles in family businesses” (Aronoff, 1998, p. 184).

3. Gender identity refers to how individuals define themselves (Dumas, 1998; Vera \& Dean, 2005) as being a woman or man according to what it means to them to be a woman or man; how it influences their selves and their lives.

"... Male grandchildren are being pushed towards the business while I, the eldest grand-daughter, am positively discouraged" (Birley, 2002, p. 18).

"Although Pierre-Karl states that he and his father were not very close, his older sister, Isabelle, sees a great resemblance between the two. ... According to Isabelle, 'Pierre- Karl resembles him in so many ways-you can understand why he always had to fight to find his own identity. My father would often say, 'That little whippersnapper, he's not going to show me.' At the same time he saw himself in Pierre-Karl: the fiery, impulsive nature, the ability to make decisions, the drive ... '” (Ibrahim, Soufani, \& Lam, 200I, p. 249).

"Because the family identity of the chief executive in family businesses is closely tied to his identity as leader of the firm, chief executives in family businesses often feel a special sense of loss when power is transferred" (Gilding et al., 20I5, p. 304). 
Table 3. (continued)

Gender theme and description

Articles with significant engagement

“ . . . being a family member or being a member of a family subgroup (e.g., based on lineage, generation, birth order, or sex) is associated with status, power (including control of the business), succession rights, or wealth distribution privileges. In these cases, category-based perceptions of others may become rigid and unlikely to change. Social distances and positions become magnified, entrenched, and difficult to bridge" (Milton, 2008, p. 1068).

4. Primogeniture as a succession process recognizes the assumption and procedure within the business family of

(Haberman \& Danes, 2007; Perricone, Earle, \& Taplin, eldest male heir succession, as well as challenges to same, for instance, gender socialization for succession of girls.

"An effective succession plan for a culture in which primogeniture cannot easily be breached might have to pay special attention to training the heir apparent. North American contexts may have more degrees of freedom ... " (Le Breton-Miller et al., 2004, p. 317).

"Gender was the most important criterion in determining who would be the successor. The rule that girls could not be family successors was publicly rejected by some parents, but quietly set in place” (Keating \& Little, 1997, p. 168).

"The first choice for successor was the only son (second child) for two reasons. First, it is a tradition for the eldest son to lead the business. Second, it is a manufacturing business and is, therefore, believed to be more suited for a male leader" (Santiago, 2000, p. 26).

"Will this trend increase the second-generation management as more qualified individuals lead the business rather than a family member who just happens to be the eldest son" (Brockhaus, 2004, p. 169)?

5. Patriarchal power refers to men in positions of power (especially, but not exclusively the father) with women

(Gilding, 2000; Haberman \& Danes, 2007; Mehrotra et al., excluded. Patriarchal gendered family hierarchies are discussed using a variety of concepts (e.g., authority, power, domination-submission, exclusion-inclusion, patrilineal, control).

"(There is a reluctance of patriarch incumbents) to share their power with other family members, irrespective of family harmony... in these circumstances, it may be difficult to distinguish harmony from compliance" (Gilding et al., 20I5, p. 305).

“Historically, family businesses commonly had 'no women' and 'no wives' rules (whether formal or informal)" (Aronoff, I998, p. 184).

"Harmonious, respectful relationships were found between fathers and sons, aged 50 to 59 and 23 to 32 , respectively. Relationships were relatively more problematic when fathers were between 60 and 69 and sons were 34 to 40 ” (Dunn, 1999, p. 44).

“. . . arranged marriages allow an incumbent family patriarch to select marriage partners for his children based first on the needs of the family business" (Mehrotra et al., 20II, p. II24).

“'Paternalistic management' was characterized by hierarchical relationships, top management control of power and authority, close supervision, and distrust of outsiders" (Sonfield \& Lussier, 2004, p. 19I).

Theme 5, patriarchal power, refers to men in positions of power (especially, but not exclusively the father) with women excluded. Patriarchal gendered family hierarchies are discussed using a variety of concepts (e.g., authority, power, domination-submission, exclusioninclusion, patrilineal, control). Patriarchy of a formal and informal kind, and its associated power, is exercised by the father (or other male leader) in the context of the family business using a large panel of notions, often interchangeably. Usually, these modes of power are not defined and, in fact, are not narratively described; they are taken-for-granted. The patriarch usually assumes decision making in the family business, including the successor choice. Some negative consequences on family harmony and on succession planning are linked to this structuring, as is a sense of order. Patriarchy sometimes actively excludes or diminishes female participation entirely.

Summary of Results. Our results on the level of engagement of gender in the historical literature, our assessment of the use of the Gender Terms Vocabulary, and our 
analysis leading to the identification of five gender themes contribute to produce the following summary findings.

Finding 1: The family business succession literature undertheorizes gender. There are important gaps in the family business succession literature in terms of gender theorization. While involving the study of a phenomenon deeply gendered, this body of scholarship fails to acknowledge or discuss the concept, its affect, and/or its dynamic nature in a meaningful and useful way. In most cases, people and situations are placed in gendered contexts, or the suggestion of a gender effect is given, without explanation or definition, and when gender concepts are engaged, little theoretical coherence or strength is expressed. As something that is, the everyday reality of doing - or undoing - gender is not in view and is not engaged. Theory from the social sciences where gender theorizing primarily lives (e.g., sociology, psychology, and philosophy) is not integrated.

As a matter of course, gendering is taken-for-granted and therefore to most readers, it remains invisible. Or readers are challenged on behalf of those therefore diminished, or their advocates (in most cases women), without a context that explicates the situation in reference to the family business dynamics. As an illustration, in none of the succession articles is primogeniture or patriarchy, core constructs of family business that are saturated in gender meaning, presented as a condition of women and men, their families and their businesses. Without a robust engagement with gender in families, it is difficult to move beyond to theorize other gender effects, for example, gendered occupations, industries, management practices, products, legal and financing structures, educational systems, research, and so on, that affect business succession deeply. We suggest this (often) atheoretical positioning disservices a robust understanding of the social arrangements of women and men engaged in family business succession.

Finding 2: When the succession literature considers gender, it regards it as a stable and objective condition of women. Research on family business succession largely approaches sex and gender as a preexisting and stable characteristic of women, a force that affects women or one that positions women in relation to men. This is an underspecified intellectual approach to gender on the following counts: gender is generally presented as a "problem" that affects women only (in particular daughters and mothers), who are then positioned as "other" (in reference to men, in particular sons and fathers), without consideration of the meaning or impact of that positioning; and in parallel, the gender and gendering of men is largely unrecognized.

The dominant ideas of gender developed in the literature involve the perceived negative impact of traditional gender norms (patriarchy) on women, and daughters particularly, leading them to no or low positions in hierarchy, responsibility, and decision making and with less preparation as children for succession. Females in leadership are considered in reference to the male norm; unusual; wives of dominant male leaders are visible in supportive, influential roles, though these may be unofficial and they may preclude a more formal role in the company due to their relations with men. We recognize a handful of articles that consider women as founders and their relationships with children or sibling groups as heirs.

The gender and gendering of men is almost unconsidered in the succession literature. Being a male, and particularly the eldest male, carries a normative assumption of power, responsibility, and participation in the business domain, and relatedly, in the family. There are hints, but not full expositions, on this not always being an easy, comfortable, or accepted role. As women gain a place at the table, and on the potential successor list, men are affected-and not just negatively. The stories are much richer and we now provide only a shadow of this in our work.

Finding 3: The succession literature demonstrates a deep tension between patriarchal and egalitarian gender norm system viewpoints. The literature reflects patriarchy and its reinforcing practice, primogeniture, as a normative standard in family business succession, whether the normative standard is present and made visible or not with regard to the family, group, or individual under study. Patriarchy involves men and women in a system that favors men for leadership roles and structures relationships and then apportions resources and assets accordingly. The stability delivered thereby has been presented as a potentially positive family business force (e.g., Haberman \& Danes, 2007; Perricone et al., 2001).

However, when it is overtly discussed, patriarchy is generally considered via a discourse of questioning (e.g., Birley, 2002; Brockhaus, 2004; Gilding, Gregory, 
\& Cosson, 2015; Haberman \& Danes, 2007; Santiago, 2000; Tatoglu, Kula, \& Glaister, 2008; Yan \& Sorenson, 2006). These works discuss an increasing acceptance of women in family business leadership roles and in ownership; the important role of spouses/sisters in joint decision making and management teams; changes in attitude toward women in leadership; and daughters' ability to fill strategic and independent founder roles as a result of higher educational levels and social changes.

Taking a position based on equality of the sexes, reinforced by egalitarian principles, authors describe family practices for successor choice and ascendancy through teams of mixed-sex successors who, for example, share ownership, power, and influence (Brockhaus, 2004; García-Álvarez, López-Sintas, \& Gonzalvo, 2002; Gilding et al., 2015; Santiago, 2000; Schröder et al., 2011; Sharma \& Rao, 2000; Tatoglu et al., 2008). This work begins to bring forward the tension between certain family values (fairness principles regarding children regardless of sex) as they are seen to be in conflict with business realities and socially embedded gender roles (e.g., primogeniture). Overall, there is an awareness that norms are changing and assumed male power related to status in the family and business hierarchy is not as taken for granted socially as it once was.

Finding 4: The succession literature embeds the gendered lens of its researchers, largely unspoken. Research (the product) and the research process (e.g., methodology, research questions, selection of setting, philosophical positioning) are not neutral as regards treatment of gender in the family business succession literature. Researchers embed a point of view into their work; we select a literature and a setting, determine what is important to study, draw conclusions, and suggest future research. Taken as a cumulative body of work, we can ask, then, what theories or philosophical positions do we take, if any, and what is the result.

Our literature review and analysis shows that family business succession research as a whole historically is atheoretical in terms of gender or it embeds a liberal feminist view of gender when gender thinking appears (e.g., Dumas, 1998; Dumas et al., 1995; Galiano \& Vinturella, 1995; Haberman \& Danes, 2007; Harveston et al., 1997; Stavrou, 1999; Vera \& Dean, 2005). Both positions make a stand in terms of describing how succession does and should work as it considers family members and stakeholders who are women and men. Scholars do evoke gender automatically as we speak of family - our language makes this inevitable so, we believe, important questions for researchers are as follows: (a) Does a lack of consideration of gender diminish or misdirect our body of findings? We conclude yes. (b) Does a fuller consideration of gender provide a route to better understand the family business succession phenomenon? Again, we suggest yes.

Let us consider one example: What is the impact on family business succession of family values related to gender and sex equality? Some studies reviewed for this article suggest how changes in gendered systems, based in a philosophy of gender equality, in conjunction with the decline of patriarchal and familistic systems, may hinder the survival and success of family businesses over multiple generations (Gilding, 2000; Mehrotra et al., 2011; Perricone et al., 2001). On the other hand, other scholars suggest that the opening up of succession pathways to women strengthens the chances of family business survival over time as heirs will be selected based on their talent, knowledge, and experience, rather than on their sex and birth order (House et al., 2004). These alternative positions suggest that a gender lens on succession provides a research pathway with value to scholarship and practice.

\section{Moving Forward: A Family Business Succession Research Agenda Integrating Gender as Socially Constructed}

So now, based on our analysis of the literature, we take up directly the second research question of this article: How can a social construction of gender lens be conceptualized to add value to family business succession research moving forward? We suggest this can be done in two ways: By revisiting and revising existing family business succession models through application of a gender lens and by integrating gender theory into new work on succession. To draw as accessible and practical a view as possible, cogently, and succinctly, we first sketch the framework of a leading gender theory in sociology, expectation states theory, drawing particularly on Ridgeway and her colleagues (Ridgeway, 2011; Ridgeway, Boyle, Kuipers, \& Robinson, 1998; Ridgeway \& Correll, 2004). Expectation states theory addresses the interpersonal and individual level of analysis representing $70 \%$ of all family business succession research per Nordqvist et al. (2013) and it is drawn within the social construction paradigm. We apply it to 
encourage interdisciplinary investigation; bridging theory from the social sciences to build theory and empirical findings on family business succession from a social construction of gender lens.

Then taking the tenets of expectation states theory, we analyze a leading model of family business succession: the Sharma and Irving (2005) model of successor commitment. We revise the model to examine how a socially constructed view of gender shifts and opens up points of view, new realizations, and questions related to the attitudes, perspectives, and behaviors of successors within their environments. We are left, we believe, with a stronger model and new research questions to explore. This exercise illustrates practically how gender can be integrated into family business scholarship either as a focal point or as a secondary but serviceable variable and/or context.

Finally, in this section, we develop a forward looking agenda for research on gender in family business succession within and across levels of analysis and across the stages of presuccession and succession. When taken up by scholars, these and other questions will lead to a forward looking, rich understanding of family business succession through a gender lens.

\section{Expectation States Theory}

Expectation states theory is a social psychological theory first proposed by Joseph Berger (J. Berger, Cohen, \& Zelditch, 1972; J. Berger, Conner, \& Fisek, 1974; J. Berger, Fisek, Norman, \& Zelditch, 1977) and now championed especially by Cecilia Ridgeway (e.g., Ridgeway, 2011; Ridgeway et al., 1998; Ridgeway \& Correll, 2004). Expectation states theory explains how the status of different social groups emerges and is perpetuated implicitly (i.e., interpersonal status processes), particularly as it relates to social inequality. While the theory was not created to address gender specifically, it has been used extensively for this purpose. Ridgeway's (2011) work details how contemporary gender stereotypes (i.e., cultural norms around what men and women are, and what they can and should be and do) incorporate status beliefs that associate greater status with a general competence to complete tasks and accomplish goals (J. Berger et al., 1977; Ridgeway \& Correll, 2004), while still allowing that each group may have some special talents. In contemporary society, this link of status and general competence is made across many stereotypes, including gender (Cuddy, Fiske, \& Glick, 2007;
Fiske, Cuddy, Glick, \& Xu, 2002; Koenig \& Eagly, 2014). On average, it has been empirically demonstrated that men hold higher status which gives them greater access to resources and power than women, all else equal (for a review, see Ridgeway, 2011). This association of status and general competence which favors men is exercised widely-both consciously and unconsciously_by men and by women (e.g., Jackman, 1994; Tilly, 1998) and it relies on a social construction metaphysical paradigm as outlined by P. L. Berger and Luckmann (1966) as considered in the front section of this article.

While an exposition on expectation states theory is beyond the scope of this article (note that Berger's students have created many tracks to this inquiry as well as extensive empirical testing), we next present five basic elements of the theory that we believe are particularly relevant and which we will use to identify gaps and opportunities for research in the family business succession literature.

1. Gender is a categorical (man-woman) form of inequality because of the implicit assumptions attached to maleness-femaleness in terms of status and competence that then result in an inequitable allocation of resources and power. Gender is an extraordinarily relevant category for social behavior because sex (man-woman), along with age, serves as a primary orienting characteristic in our interpersonal relations-people are sex categorized in almost every encounter. Put simply, gender usually influences positively for men and negatively for women at some level.

2. Gender is only one contributor to a holistic identity that is used by humans to confer status as they orient and act in social situations. Other contributors include demographic categories (race, ethnicity) as well as situational categories such as roles and titles (boss, CFO, MBA holder). Gender, along with other identity dimensions, is more or less salient in a given situation based on many factors and therefore the strength of its influence will vary depending on the circumstances in which it is enacted. Gender is made more salient, for instance, in mixed-sex groups (e.g., a sibling group); when the task at hand, its goal, or its context, can be considered gendered (e.g., the occupation of nursing or a high-tech products conference); and when individuals 
strongly embrace the cultural norm assigned to them (e.g., "I am the first-born son").

3. The gender status-competence link is created and expressed interpersonally. Its affect will be felt by men and women individually and will lead to their enacting the expectations of themselves that are self- and other-generated. Gender expectations on women can become a self-fulfilling prophecy leading men and women to see women as holding less status and competence for task achievement, and therefore, they do. Furthermore, status beliefs spread when people are treated in ways consistent with the beliefs (Ridgeway \& Erickson, 2000).

4. While gender stereotypes are active interpersonally in a sustained fashion, over the past 50 years in the Western world (and beyond), political, institutional, economic, and social efforts to establish a standard of gender equality have created an alternative cultural norm that challenges traditional gender stereotypes based on the assumed status-competence link.

5. Gender effects are especially pronounced in the spheres of work and home - the primary domains of family business (Ridgeway, 2011).

\section{The Value of a Gender Lens to Existing Theory: Considering the Sharma and Irving (2005) Model of Successor Commitment}

We now examine and reconceptualize the Sharma and Irving (2005) model of family business successor commitment to illustrate how existing models of family business may be enriched by gender theorization providing new questions for scholarship. We chose this model as an example of a family business succession research framework that is highly respected, well-cited, and has been empirically tested (Dawson, Irving, Sharma, Chirico, \& Marcus, 2014; Dawson, Sharma, Irving, Marcus, \& Chirico, 2015). It is also one of the few succession models that has acknowledged and integrated sex and gender ideas. Please note this is not a criticism of the model-far from it. All researchers must make decisions about which elements are the most important to bring forward in their work. Rather, it is an effort to show how thoughts on the social construction of gender can be used to take good ideas further; the scholarly task.
To review, the model developed by Sharma and Irving (2005) expands understanding of family business successor commitment, treated historically as a onedimensional concept. The model identifies four bases of successor commitment-affective (perceived desire), normative (perceived sense of obligation), calculative (perceived opportunity costs), and imperative (perceived need) - and discusses their effect on the successor's discretionary behavior and "decision to exert efforts beyond the call of duty." Each base of commitment is informed by different psychological, sociological, and economic forces: the "antecedents".

Gender is included in the Sharma and Irving (2005, p. 21) model as an element of the antecedent of one of the commitment bases - the normative base: "familial norms with respect to gender and birth order/institutionalization of norms." These family norms are hypothesized to affect the obligation-based behaviors of family members with regard to succession, for example, the son's assumption under family norms of primogeniture that he should and will step up to perpetuate the family firm in the next generation as well as the daughter's assumption that she will not.

Applying the ideas of expectation states theory outlined above, we revise the Sharma and Irving model (Figure 1) to reveal the impact of a social construction of gender lens on model elements, on their relationships, and on the model's potential predictions and associations related to successor commitment. We title the revised model: A gendered extension of the Sharma and Irving (2005) model of family business successor commitment (the extended model). Below, we discuss in four parts the revision of the model and its implications.

Revision I (RI-Figure I). Considered in Ridgeway's (2011) research as a primary-orienting social characteristic of groups, gender plays a role, in the background or in the foreground, while other processes such as family business succession take place. Therefore, we posit that socially constructed gender norms influence all model elements, not just the normative commitment as the original model suggests, and therefore, gender operates in a role foundational to the family rather than simply as a function of the family. Therefore, in addition to normative commitment, gender also influences affective commitment (How does gender influence my identity and interests?), calculative commitment (How does gender influence my other career choices and my opportunity 


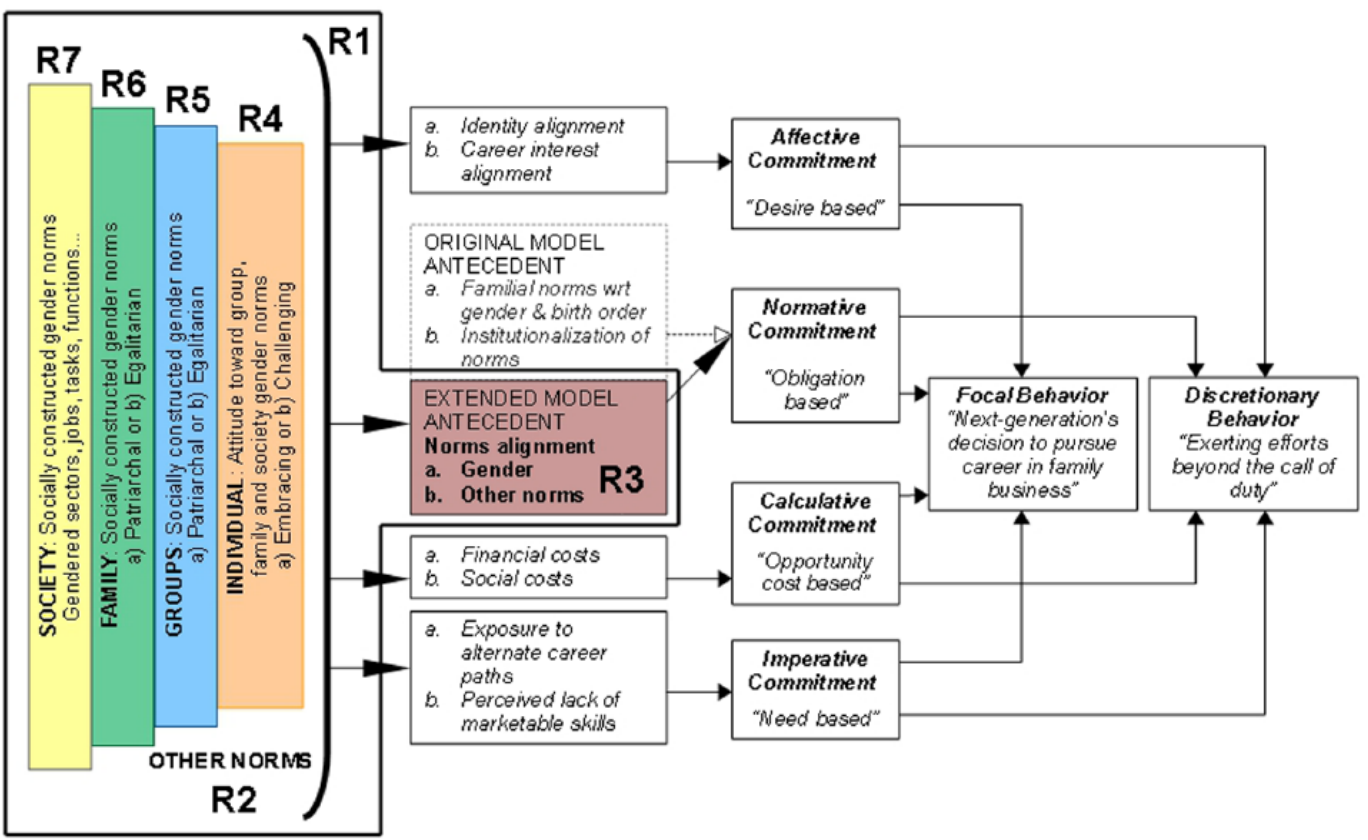

Figure I. A gendered extension of the Sharma and Irving (2005) model of family business successor commitment (original is italicized; revision is not).

Note. Proposition relationships in the original model have been deleted for clarity.

Source. Sharma and Irving (2005, p. 20).

costs?), and imperative commitment (How does gender influence how I have been prepared for a work life?). Gender is then specified to shape the potential successor's commitment, the antecedents to those commitments, and the outcome behavior in potentially complex ways.

Revision 2 (R2-Figure I). Expectation states theory brings forward other social dimensions that also influence the full model and may sit alongside, override, strengthen, or mitigate gender norms in evaluation of status and competence, depending on the context and the salience of gender situationally. Therefore, the extended model recognizes norms beyond gender that may play a role in determining the direction and strength of successor commitment and decision to go beyond the call of duty, for example, birth order (identified in the original Sharma and Irving model) as well as the following: age and relative age of family members; family structure including number of children, age gaps, group sex composition; religion and spirituality; ethnicity; nationality; political orientation; sexual orientation; wealth and economic status; immigrant status; community and family engagement; and other cultural and social factors.

Revision 3 (R3-Figure I). With the shift of gender and other institutionalized norms to a supra model level, we then propose in the extended model a new antecedent for the normative commitment that we title: "Norms Alignment." With this change, all antecedents in the model are now at the individual level, that is, with the potential successor. This revision allows us to begin to consider the harmony or disharmony of norms held by the successor, the family, and the extended family group relative to gender. Based on ideas of expectation states theory, individuals (here the daughters or sons) enact self-perceived norms and expectations in their interpersonal relations, within systems also characterized by social and cultural norms which may or may not ally. So, for instance, we can ask, within an overall patriarchal family system,: how does the strength of the daughter's alignment with that gender norm predict the likelihood 
of her engagement with the family business as well as the intensity of her decision to go beyond the call of duty? And for an egalitarian-oriented son, there is more explanatory power in the extended model as it breaks the assumption that norms align across a family wholesale.

Revisions 4 to 6 (R4, R5, R6-Figure I). With these revisions, the extended model establishes that successors and their family groups may align - or not - on gender norms. Revision 4 addresses the successor's position relative to the family; Revision 5, the alignment of gender norms across and between groups including sibling, parent, cousin, employee, or other groups in the family business constellation; and with Revision 6 , the overall family tradition, perhaps historically molded, influences expectations for successor engagement based on gender. Families, family groups, and players' significant others/ spouses, may, for instance, be in unity or conflict regarding succession practices. For example, the individual may hold views in conflict with siblings or the siblings as a group may hold views in conflict with the father, or mother, or parent group. Furthermore, the mother may hold views different than her husband which, due to gender norms, affect the sons and daughters differently (and she cares about this very much, or not so much). In such a case, when the mother is the CEO and founder, there may be a different hypothesized outcome than when the father is CEO and founder. There are many interesting dynamics at play here and when gender is taken as a system, it becomes clear that gender norms may evolve and interplay over time in significant ways.

Revision 7 (R7-Figure I). Expectation states theory highlights gender as a social, interpersonal, cultural normative system operating continuously in various spheres (Ridgeway, 2011). Therefore, occupations, organizations, industries, laws and regulations, media, and culture, among other social organizing, may be considered gendered (Ahl, 2004, 2006; Calás et al., 2009; Ely \& Padavic, 2007). This is relevant to family business succession, for example, in relation to gendered industries (e.g., fashion vs. computer hardware) and gendered business roles (human resources vs. finance). The pattern of women's participation as founders, leaders, and successors (Jennings \& Brush, 2013) and the government policies that set standards and provide resources to businesses (Ahl \& Nelson, 2015) have also been established as gendered. We could see this acting, for instance, when the family, sibling team, and individual hold strong gender egalitarian values, while the society holds strong patriarchal views.

To summarize, these seven revisions to the Sharma and Irving (2005) model of successor commitment open up our view to the kind, degree, interaction, and dynamic nature of gender norms across levels of analysis (society, family, group, and individual), among groups, and for individuals and individual pairs. Gender norms can then be hypothesized to strengthen, or weaken, or otherwise change successor commitment and its antecedents, we posit. These ideas are far from an exhaustive set, yet they begin to suggest the complexity and importance of a gender view on family business succession expectations and outcomes.

\section{Recommendations for Future Research: Integrating New Gender Questions and Theories}

In this section, we take the next step and share a range of potential future research questions to relate a socially constructed gender view to the family business succession phenomenon. We also provide introductions to recognized theoreticians and work that can lead family business scholars to fuller integration of gender theory rooted in the social sciences and humanities.

Table 4 presents a robust set of forward looking research questions organized by level of analysis (society, family, group and individual, and multilevel) and across succession stages (succession planning and succession/postsuccession). Inspired by expectation states theory, we consider the influence of societal, family, and group gender dynamics on succession, for example, how do changes in practices and views of marriage affect family business longevity? We recommend that a gender lens be applied to study men's realities in family business succession, and propose some relevant areas for investigation, for instance, what are the constraints of the dominant models of masculinity for sons in family businesses? Instead of taking gender as a condition of women and their bodies, we suggest research on how individuals, groups, and families $d o$ gender and construct gender norms: How are the family gender norms and business governance modes reproduced or transformed from one generation to another? And we acknowledge norms other than gender that influence 
Table 4. Potential Research Questions Relating Gender and Family Business Succession by Succession Stage and Level of Analysis.

\begin{tabular}{|c|c|c|}
\hline & Succession planning & Succession/postsuccession \\
\hline $\begin{array}{l}\text { Societal level of } \\
\text { analysis }\end{array}$ & $\begin{array}{l}\text { What is the impact of globalized media on the } \\
\text { diffusion of perceptions of gender and how does } \\
\text { this influence family decisions regarding successor } \\
\text { choice? } \\
\text { How do cultural norms and practices across world } \\
\text { cultures deliver varied structures for succession } \\
\text { planning decision making? }\end{array}$ & $\begin{array}{l}\text { How does the evolution of egalitarian views } \\
\text { of gender modify family business operations } \\
\text { when the company is taken over by the next } \\
\text { generation? } \\
\text { How do changes in practices and views of } \\
\text { marriage (e.g., a decrease in use in Western } \\
\text { societies) affect family business structure, } \\
\text { longevity, and/or performance? }\end{array}$ \\
\hline $\begin{array}{l}\text { Family level of } \\
\text { analysis }\end{array}$ & $\begin{array}{l}\text { How do nonnuclear families plan succession? What } \\
\text { are the roles of family members in the development } \\
\text { of the successor's resources in such nonnuclear } \\
\text { families, and how do they affect succession planning? } \\
\text { Since the number of leadership positions in the } \\
\text { firm are generally restricted, how do egalitarian } \\
\text { style families use the ideas of equity and equality } \\
\text { to apportion ownership and roles in succession } \\
\text { planning? } \\
\text { Children as a family set will present different numbers } \\
\text { and ratios of male/female per family successor } \\
\text { group. How does a gendered lens to the sex } \\
\text { difference classification of the successor pool } \\
\text { express itself in family succession decisions? }\end{array}$ & $\begin{array}{l}\text { How do family firms position in terms of } \\
\text { company gender norms and what effect } \\
\text { does this have on corporate identity and } \\
\text { performance? } \\
\text { How does the salience of different identity } \\
\text { dimensions, including race and ethnicity, affect } \\
\text { gender expression and family succession } \\
\text { outcomes (e.g., African Americans in the United } \\
\text { States hold more equal views of men and } \\
\text { women than Whites per Ridgeway, 20II)? }\end{array}$ \\
\hline $\begin{array}{l}\text { Group level of } \\
\text { analysis }\end{array}$ & $\begin{array}{l}\text { How do siblings as a team build alliances and } \\
\text { participate in decisions regarding succession? How } \\
\text { do the gender and sex compositions of children } \\
\text { influence parent succession thinking and behavior? } \\
\text { How do parent views on gender influence the } \\
\text { potential successor set, reaching out to cousins and } \\
\text { uncles, for instance? What influence does this have } \\
\text { on the firm as it prepares for a new successor? }\end{array}$ & $\begin{array}{l}\text { How are intrafamily power relations affected by } \\
\text { generational values on gender? What affect do } \\
\text { these power relations have on family harmony } \\
\text { during succession and in the long-run? } \\
\text { How do gender norms in society and family affect } \\
\text { the way siblings-daughters and sons-position } \\
\text { individually and as a group over time? }\end{array}$ \\
\hline $\begin{array}{l}\text { Individual level of } \\
\text { analysis }\end{array}$ & $\begin{array}{l}\text { How do different gender expectations (self-, family-, } \\
\text { business-generated, etc.) influence the willingness } \\
\text { and attitudes of potential successors to take over } \\
\text { the firm? } \\
\text { What are the useful family business competences and } \\
\text { skills of the leader's spouse or significant others? } \\
\text { How can these competences and skills contribute to } \\
\text { the successor's preparation and to the succession } \\
\text { planning process? }\end{array}$ & $\begin{array}{l}\text { After succession takes place, how does a father } \\
\text { patriarch reconcile his role in the family } \\
\text { and his advisory role in the business, from a } \\
\text { psychological perspective? What affect does } \\
\text { the father's double role have on postsuccession } \\
\text { performance? What role does gender play? } \\
\text { What are the constraints of the dominant models } \\
\text { of masculinity for sons in family businesses? } \\
\text { How do they affect the sons' positioning in the } \\
\text { family and family business? }\end{array}$ \\
\hline $\begin{array}{l}\text { Multilevels of } \\
\text { analysis }\end{array}$ & $\begin{array}{l}\text { How do the gender norms of sibling groups align with } \\
\text { the family, firm, and social norms? How does this } \\
\text { affect the predecessors (and/or predecessor group) } \\
\text { and successors attitudes toward succession for the } \\
\text { firm? } \\
\text { How do families, groups, and individuals integrate } \\
\text { ideas of gender to consider fair treatment (equity) } \\
\text { versus equal treatment (equality) in the allocation of } \\
\text { roles, authority and wealth? }\end{array}$ & $\begin{array}{l}\text { To what extent are egalitarian gender norms } \\
\text { regarding succession extended from the family } \\
\text { to the firm? Under what conditions do family } \\
\text { firms change, and how? } \\
\text { How are the family gender norms and business } \\
\text { governance modes reproduced or transformed } \\
\text { from one generation to another? What are the } \\
\text { levers of transformation? }\end{array}$ \\
\hline
\end{tabular}


family business succession processes: How does the salience of different identity dimensions, including race and ethnicity, affect gender expression, and family succession outcomes?

For scholars who want to explore work in business and management that integrates gender as a construct, we identify here writings that serve as good introduction points. These gender researchers use a social construction paradigm to study the systematic, interwoven, and dynamic forces acting on people, objects, bodies, activities, and processes as well as on business social arrangements such as norms, rules, culture, industries, politics, policies, law, hierarchy, and power (e.g., Ahl, 2006; Ahl \& Marlow, 2012; Ahl \& Nelson, 2015; Calás et al., 2009; Chasserio, Pailot, \& Poroli, 2014; Constantinidis \& Nelson, 2009; Cornet, 2002; de Bruin, Brush, \& Welter, 2007; Díaz García \& Welter, 2011; Ely \& Padavic, 2007; Fischer, Reuber, \& Dyke, 1993; Gupta, Turban, Wasti, \& Sikdar, 2009; Holmquist \& Carter, 2009; Jennings \& Brush, 2013; Orser, Elliott, \& Leck, 2013; Redien-Collot, 2009).

There are in addition, many other theories and theorists of gender in the social sciences and humanitiessome social constructionist and others not - that have relevance to family business succession concerns and to the specific questions and domains posed in Table 4. Experts and their foci can be identified via the core list of Journals for Women and Gender Studies (2015) and through the work of the following selectively listed who are very well regarded and cited widely across disciplines engaging gender: Judith Butler (2006; gender performativity); Dorothy Smith (1987; standpoint theory); Carol Gilligan (1977; psychological theory and women's development); Nancy Chodorow (1999; feminist psychoanalysis); bell hooks (2014; race, gender, and class intersectionality); Patricia Collins (2008, Black feminist thought); Lawrence Kohlberg (2011; gender cognitive-developmental analysis); Michel Foucault (1980a, 1980b; power and the body-individual and social); Sandra Bem (1994; gender schema theory); Raewyn Connell (2014; masculinities).

\section{Discussion}

Zell, Krizan, and Teeter (2015) tell us that in addition to age and race, sex is perhaps the most salient category that guides us in our social perception of people. As a matter of course, we draw inferences about the people we encounter from visual cues about the body-sex (Ito
\& Urland, 2003) fitting those cues into our constructions that have been built socially about what men can and should do, and what women can and should do-gender (Ahl \& Nelson, 2015).

Our goal in conducting this research was to investigate these ideas in the context of family business succession research - to assess where we are and to see what more can be explored and learned by integrating a social construction of gender lens. Our 20-year literature review gave us perspective on the research tradition-it delivered results showing that ideas of gender are present, yet currently undertheorized and open for exploration on more levels of analysis and with more robust theoretical approaches. Seen as a socially constructed phenomenon, gender acts in profound and varied ways within the family and the family business during succession.

This research also allowed us to acknowledge the contributions that have been made to date within our body of scholarship. Some of the earliest work concerning family business succession brought us an awareness of gendered discourse in terms of role expectations; for example, the family firm daughter as "daddy's little girl" (Dumas, 1989, p. 37). Other work explored gendered media representations (Bjursell \& Bäckvall, 2011) and the role of narrative in setting, enforcing, and challenging norms (Danes, Haberman, \& McTavish, 2005; Hamilton, 2006). A community of researchers are using gender in their work in business and management with links to the social sciences and humanities. Gender is embedded in our discussion already; a more robust attention for its exploration can now be built.

Looking forward, we demonstrated how gender theory can inform existing succession research. We mobilized expectation states theory with a gender lens to consider and revise the respected Sharma and Irving (2005) model of successor commitment. This project demonstrated that gender theory has much to add to our current thinking on succession attitudes and processes. Family relations force the issues of gender forward, for example, as predecessors reconcile the sex of their children with their business plans, as sibling and parent groups hold different gender identities with implication for leadership structures. Variability in gender beliefs and norms exist across families and cultures. This complex social system plays out in the family business succession landscape providing rich material for scholarship.

Then we moved to consider new research questions. We shared a rich trove of research questions ready to be explored at the intersection of social norms and 
succession. Taken up, this nonexhaustive list can form the nucleus of a new platform of study on gender and succession. To support such scholarship, we recognized key scholars in business and management and beyond who center stage or integrate gender into their scholarly point of view.

We see our work as opening the way for more interdisciplinary work that can create robust lines of investigation in family business. In addition, we can move succession scholarship beyond a concern with women only-issues of gender and men are fascinating and not explored. We see real opportunity for our community to develop both conceptual and empirical work on succession that takes the variable of sex and the construct of gender together into account for the people involved: fathers, sons, mothers, daughters, and other family and nonfamily individuals. While "gender studies" over the past three decades has been taken as largely engaged and synonymous with "women's studies," that paradigm is breaking (e.g., Journal of Men's Studies-Sage, American Men's Studies Association).

Furthermore, in light of the purpose of gender theory as socially constructed, we encourage family business succession researchers to view gender as a pervasive force influencing not only women and men but also families, businesses, networks, research, language, competition, and beyond. Processes, discussions, products, and industries (and more) can be seen to be gendered insofar as norms around men and women, and maleness and femaleness, are defined and taken for granted. Perhaps an embrace of this can encourage researchers to tread lightly in using a primary independent variable of sex (i.e., men do this and women do that) as a research variable and motivator. This approach at best only scratches the surface and at worst misdirects our understanding of men and women as it forces our attention to the mean: binary is a pretty crude cut. How gender through sex classifications influences family structures, trajectories, functions, and interactions as well as business processes, structures, and decisions is a better starting point, we have come to believe. It also heads toward a stronger account of the diversity of family patterns within and across societies thereby enriching our knowledge on family businesses, answering the recent call of Jaskiewicz and Dyer (2017).

We aspire that our work advance the idea that gender should be added to the set of constructs considered routinely when theory and empirical studies are built on family business succession. This requires that researchers identify their own gender lens and those of their subjects, an identification that has to date remained largely unconsidered and unspoken. Researchers act on the data as they investigate it. As feminists, we support the egalitarian view of gender over the patriarchal; however, this position is not required to understand and integrate gender as a research lens. In fact, we will not have a clear sight of our subject if we cannot appreciate their gender views where they are. To do this, we need to work to disentangle our convictions from theirs.

\section{Conclusion}

A social construction of gender lens can advance our understanding of family business succession. Building new theory approaches to the subjects and topics of our domain, together with careful articulation and analysis of empirical variables related to sex and gender, will inform key processual and outcome topics to the benefit of policy makers, academics, allied consultants, media and family business members, and other stakeholders. We welcome and encourage the continued building of a community in family business around these topics.

\section{Declaration of Conflicting Interests}

The author(s) declared no potential conflicts of interest with respect to the research, authorship, and/or publication of this article.

\section{Funding}

The author(s) received no financial support for the research, authorship, and/or publication of this article.

\section{Notes}

1. Some gender scholars dispute sex as a fixed biological binary. For more, see Butler (2006). We set this argument respectfully to the side in this work.

2. Standpoint theory takes its roots in Hegel's (1977) idea that oppression and injustice are better analyzed from the slave's point of view and in Marx's (1959) and Lukács' (1968) subsequent work around class relations and the standpoint of proletariat. A central assumption is that an epistemic agent's social situation influences the production of knowledge. Criticizing mainstream research, based on the dominant group's perspective, standpoint theorists assume research's inherent subjectivity and give voice to the marginalized groups, representing a particular and advantaged epistemic position.

3. In reporting and discussing results, the reader can assume that the use of any vocabulary term includes all derivative terms - for example, wife and wives. 


\section{References}

Accenture. (2015). The "greater" wealth transfer: Capitalizing on the intergenerational shift in wealth. Retrieved from https://www.accenture.com/in-en/ /media/Accenture/ Conversion-Assets/DotCom/Documents/Global/PDF/ Industries_5/Accenture-CM-AWAMS-Wealth-TransferFinal-June2012-Web-Version.pdf

Ahl, H. (2004). The scientific reproduction of gender inequality: A discourse analysis of research texts on women's entrepreneurship. Malmö, Sweden: Liber AB.

Ahl, H. (2006). Why research on women entrepreneurs needs new directions. Entrepreneurship: Theory and Practice, 30, 595-621. doi:10.1111/j.1540-6520.2006.00138.x

Ahl, H., \& Marlow, S. (2012). Exploring the dynamics of gender, feminism and entrepreneurship: Advancing debate to escape a dead end? Organization, 19, 543-562.

Ahl, H., \& Nelson, T. (2015). How policy positions women entrepreneurs: A comparative analysis of state discourse in Sweden and the United States. Journal of Business Venturing, 30, 273-292.

Aronoff, C. E. (1998). Megatrends in family business. Family Business Review, 11, 181-185.

Bain, D. (2015). The top 500 family businesses in the world. Retrieved from https://familybusiness.ey-vx.com/pdfs/182187.pdf

Bem, S. L. (1994). The lenses of gender: Transforming the debate on sexual inequality. New Haven, CT: Yale University.

Berger, J., Cohen, B. P., \& Zelditch, M. (1972). Status characteristics and social interaction. American Sociological Review, 37, 241-255.

Berger, J., Conner, T. L., \& Fisek, M. H. (1974). Expectation states theory: A theoretical research program. Cambridge, MA: Winthrop.

Berger, J., Fisek, M. H., Norman, R., \& Zelditch, M. (1977). Status characteristics and social interaction. New York, NY: Elsevier.

Berger, P. L., \& Luckmann, T. (1966). The social construction of reality: A treatise in the sociology of knowledge. London, England: Penguin Books.

Birley, S. (2002). Attitudes of owner-managers' children towards family and business issues. Entrepreneurship: Theory and Practice, 26(3), 5-20.

Bjursell, C., \& Bäckvall, L. (2011). Family business women in media discourse: The business role and the mother role. Journal of Family Business Management, 1, 154-173.

Brockhaus, R. H. (2004). Family business succession: Suggestions for future research. Family Business Review, 17, 165-177.

Butler, J. (2006). Gender trouble: Feminism and the subversion of identity. New York, NY: Routledge Classics.

Calás, M. B., Smircich, L., \& Bourne, K. A. (2009). Extending the boundaries: Reframing "entrepreneurship as social change" through feminist perspectives. Academy of Management Review, 34, 552-569.
Casillas, J. C., Acedo, F. J., \& Moreno, A. M. (2007). International entrepreneurship in family businesses. Cheltenham, England: Edward Elgar.

Chasserio, S., Pailot, P., \& Poroli, C. (2014). When entrepreneurial identity meets multiple social identities: Interplays and identity work of women entrepreneurs. International Journal of Entrepreneurial Behavior \& Research, 20, 128-154.

Chodorow, N. (1999). The reproduction of mothering. Psychoanalysis and the sociology of gender (2nd ed.). Oakland: University of California.

Collins, P. H. (2008). Black feminist thought: Knowledge, consciousness, and the politics of empowerment. New York, NY: Routledge.

Connell, R. (2014). The study of masculinities. Qualitative Research Journal, 14, 5-15.

Constantinidis, C., \& Nelson, T. (2009). Integrating succession and gender issues from the perspective of the daughter of family enterprise across the U.S. and EU. International Management, 14(1), 43-54.

Cornet, A. (2002). Gender mainstreaming and sex-differentiated approach: What effects for management? International Management, 7(1), 1-10.

Cuddy, A. J. C., Fiske, S. T., \& Glick, P. (2007). The BIAS map: Behaviors from intergroup affect and stereotypes. Journal of Personality and Social Psychology, 92, 631-648.

Danes, S. M., Haberman, H. R., \& McTavish, D. (2005). Gendered discourse about family business. Family Relations, 54, 116-130.

Daspit, J. J., Holt, D. T., Chrisman, J. J., \& Long, R. G. (2015). Examining family firm succession from a social exchange perspective: A multiphase, multistakeholder review. Family Business Review, 29, 44-64.

Dawson, A., Irving, P. G., Sharma, P., Chirico, F., \& Marcus, J. (2014). Examining the behavioral outcomes of family business successor commitment. European Journal of Work and Organizational Psychology, 23, 570-581.

Dawson, A., Sharma, P., Irving, P. G., Marcus, J., \& Chirico, F. (2015). Predictors of later generation family members' commitment to family enterprises. Entrepreneurship: Theory and Practice, 39, 545-569.

de Beauvoir, S. (1953). The second sex. New York, NY: Knopf.

de Bruin, A., Brush, C. G., \& Welter, F. (2007). Advancing a framework for coherent research on women's entrepreneurship. Entrepreneurship: Theory and Practice, 31, 323-339.

Díaz García, M.-C., \& Welter, F. (2011). Gender identities and practices: Interpreting women entrepreneurs' narratives. International Small Business Journal, 31, 384-404.

Dumas, C. (1989). Understanding of father-daughter and father-son dyads in family-owned businesses. Family Business Review, 2, 31-46. 
Dumas, C. (1998). Women's pathways to participation and leadership in the family-owned firm. Family Business Review, 11, 219-228.

Dumas, C., Dupuis, J., Richer, F., \& St-Cyr, L. (1995). Factors that influence the next generation's decision to take over the family farm. Family Business Review, 8, 99-120.

Dunn, B. (1999). The family factor: The impact of family relationship dynamics on business-owning families during transitions. Family Business Review, 12, 41-57.

Durkheim, E. (1938). Rules of the sociological method. Chicago, IL: University of Chicago.

Durkheim, E. (1951). Suicide. New York, NY: Free Press.

Eagly, A. H. (2009). The his and hers of prosocial behavior: An examination of the social psychology of gender. American Psychologist, 64, 644-658.

Ely, R., \& Padavic, I. (2007). A feminist analysis of organizational research on sex differences. Academy of Management Review, 32, 1121-1143.

European Commission. (2009, November). Overview of family business relevant issues: Research, networks, policy measures and existing studies (Final report of the Expert Group). Retrieved from file://C:/Users/QuADS-OO_002/ Desktop/family_business_expert_group_report_en.pdf

Fernández-Aráoz, C., Iqbal, S., \& Ritter, J. (2015). Why family firms in East Asia struggle with succession. Harvard Business Review. Retrieved from https://hbr.org/2015/03/ why-family-firms-in-east-asia-struggle-with-succession\#

Fischer, E. M., Reuber, A. R., \& Dyke, L. S. (1993). A theoretical overview and extension of research on sex, gender, and entrepreneurship. Journal of Business Venturing, 8, 151-168.

Fiske, S. T., Cuddy, A. J. C., Glick, P., \& Xu, J. (2002). A model of (often mixed) stereotype content: Competence and warmth respectively follow from perceived status and competition. Journal of Personality and Social Psychology, 82, 878-902.

Foucault, M. (1980a). Body/power. In C. Gordon (Ed.), Power/knowledge: Selected interviews and other writings, 1972-1977 (pp. 55-62). Birmingham, England: Harvester Wheatsheaf.

Foucault, M. (1980b). Truth and power. In C. Gordon (Ed.), Power/knowledge: Selected interviews and other writings, 1972-1977 (pp. 109-133). Birmingham, England: Harvester Wheatsheaf.

Foucault, M. (1995). Discipline and punish: The birth of the prison (2nd ed.). New York, NY: Random House.

Galiano, A., \& Vinturella, J. (1995). Implications of gender bias in the family business. Family Business Review, 8, 177-188.

García-Álvarez, E., López-Sintas, J., \& Gonzalvo, P. S. (2002). Socialization patterns of successors in first-to second-generation family businesses. Family Business Review, 15, 189-203.
Gilding, M. (2000). Family business and family change: Individual autonomy, democratization, and the new family business institutions. Family Business Review, 13, 239-249.

Gilding, M., Gregory, S., \& Cosson, B. (2015). Motives and outcomes in family business succession planning. Entrepreneurship: Theory and Practice, 39, 299-312.

Gilligan, C. (1977). In a different voice: Psychological theory and women's development. Boston, MA: Harvard University.

Gupta, V. K., Turban, D. B., Wasti, S. A., \& Sikdar, A. (2009). The role of gender stereotypes in perceptions of entrepreneurs and intentions to become an entrepreneur. Entrepreneurship: Theory and Practice, 33, 397-417.

Haberman, H., \& Danes, S. M. (2007). Father-daughter and father-son family business management transfer comparison: Family FIRO model application. Family Business Review, 20, 163-184.

Hacking, I. (1999). The social construction of what? Cambridge, MA: Harvard University.

Hamilton, E. (2006). Whose story is it anyway? Narrative accounts of the role of women in founding and establishing family businesses. International Small Business Journal, 24, 253-271.

Harding, S. (1993). Rethinking standpoint epistemology: What is "strong objectivity?" In L. Alcoff \& E. Potter (Eds.), Feminist epistemologies (pp. 49-82). New York, NY: Routledge.

Harding, S. (2010). Standpoint methodologies and epistemologies: A logic of scientific inquiry for people. In World social science report: Knowledge divides (pp. 173-175). Paris, France: UNESCO.

Hartsock, N. (1997). Comment on Hekman's "Truth and Method: Feminist Standpoint Theory Revisited": Truth or justice? Journal of Women in Culture and Society, 22, 367-374.

Hartsock, N. (2004). The feminist standpoint: Developing the ground for a specifically feminist historical materialism. In S. Harding (Ed.), The feminist standpoint theory reader: Intellectual and political controversies (pp. 3554). New York, NY: Routledge.

Harveston, P. D., Davis, P. S., \& Lyden, J. A. (1997). Succession planning in family business: The impact of owner gender. Family Business Review, 10, 373-396.

Hegel, G. W. F. (1977). Phenomenology of spirit. Oxford, England: Clarendon Press.

Holmquist, C., \& Carter, S. (2009). The Diana project: Pioneering women studying pioneering women. Small Business Economics, 32, 121-128.

hooks, b. (2014). Feminism is for everybody: Passionate politics. New York, NY: Routledge.

House, R. J., Hanges, P. J., Javidan, M., Dorfman, P., \& Gupta, V. (2004). Culture, leadership, and organizations: The GLOBE study of 62 societies. Thousand Oaks, CA: Sage. 
Ibrahim, A., Soufani, K., \& Lam, J. (2001). A study of succession in a family firm. Family Business Review, 14, 245-258.

Ito, T. A., \& Urland, G. R. (2003). Race and gender on the brain: Electrocortical measures of attention to race and gender of multiply categorizable individuals. Journal of Personality and Social Psychology, 85, 616-626.

Jackman, M. R. (1994). The velvet glove: Paternalism and conflict in gender, class, and race relations. Berkeley: University of California.

Jaskiewicz, P., \& Dyer, W. G. (2017). Addressing the elephant in the room: Disentangling family heterogeneity to advance family business research. Family Business Review, 30, 111-118.

Jennings, J. E., \& Brush, C. G. (2013). Research on women entrepreneurs: Challenges to (and from) the broader entrepreneurship literature? Academy of Management Annals, 7, 663-715.

Keating, N. C., \& Little, H. M. (1997). Choosing the successor in New Zealand family farms. Family Business Review, 10, 157-171.

Koenig, A. M., \& Eagly, A. H. (2014). Evidence for the social role theory of stereotype content: Observations of groups' roles shape stereotypes. Journal of Personality and Social Psychology, 107, 371-392.

Koh, A., Ling, C., Kong, E., \& Ejercito, J. (2015). Riding on Asia's economic transformation: Growth strategies of Asian business families. Singapore: Singapore Management University.

Kohlberg, L. (2011). The measurement of moral judgment. Cambridge, England: Cambridge University.

Kurzo, C., \& Jaecklin, S. (2014, November). The future of European wealth management: Imperatives for success. Retrieved from http://www.oliverwyman.com/content/ dam/oliver-wyman/global/en/2015/jan/The_Future_of_ European_Wealth_Management.pdf

Le Breton-Miller, I., Miller, D., \& Steier, L. P. (2004). Toward an integrative model of effective FOB succession. Entrepreneurship: Theory and Practice, 28, 305-328.

Lukács, G. (1968). History and class consciousness: Studies in Marxist dialectics. London, England: Merlin.

Marx, K. (1959). Capital: A critique of political economy (Vol. 3). London, England: Lawrence and Wishart.

Marx, K. (2010). A contribution to the critique of political economy. In J. F. Sitton (Ed.), Marx today: Selected works and recent debates (pp. 91-94). New York, NY: Palgrave Macmillan.

MassMutual Financial Group/Raymond Institute. (2003). American family business survey. Retrieved from http:// www.fambiz.org.au/wp-content/uploads/2003-MassMutual-FB-Survey.pdf

Matthews, C. H., Moore, T. W., \& Fialko, A. S. (1999). Succession in the family firm: A cognitive categorization perspective. Family Business Review, 12, 159-169.
Mehrotra, V., Morck, R., Shim, J., \& Wiwattanakantang, Y. (2011). Must love kill the family firm? Some exploratory evidence. Entrepreneurship: Theory and Practice, 35, 1121-1148.

Milton, L. P. (2008). Unleashing the relationship power of family firms: Identity confirmation as a catalyst for performance. Entrepreneurship: Theory and Practice, 32, 1063-1081.

Moore, L., \& Gupta, V. (2007). Overview of gender in family business. In V. Gupta, N. Levenburg, L. L. Moore, J. Motwani, \& T. V. Schwarz (Eds.), Culturally-sensitive models of gender in family business: A compendium using the globe paradigm (pp. 3-21). Hyderabad, Andhra Pradesh, India: Icfai University Press.

Nordqvist, M., Wennberg, K., \& Hellerstedt, K. (2013). An entrepreneurial process perspective on succession in family firms. Small Business Economics, 40, 1087-1122.

Orser, B., Elliott, C., \& Leck, J. D. (2013). Entrepreneurial feminists: Perspectives about opportunity recognition and governance. Journal of Business Ethics, 115, 241-257.

Perricone, P. J., Earle, J. R., \& Taplin, I. M. (2001). Patterns of succession and continuity in family-owned businesses: Study of an ethnic community. Family Business Review, 14, 105-121.

Poza, E., \& Messer, T. (2001). Spousal leadership and continuity in the family firm. Family Business Review, 14, 25-36.

PwC Family Business Survey. (2012). The family firm: Central to the success of the Middle East. Retrieved from https://www.pwc.com/m1/en/publications/documents/ family-firm-english.pdf

PwC Family Business Survey. (2013). Family firm: The India perspective. Retrieved from https://www.pwc.in/ assets/pdfs/family-business-survey/family-business-survey-2013.pdf

Redien-Collot, R. (2009). Female entrepreneurs' authority: Is the creative aspect of authority a masculine fiction in managerial and entrepreneurial paradigms? Journal of Enterprising Culture, 17, 419-441.

Ridgeway, C. L. (2011). Framed by gender: How gender inequality persists in the modern world. Oxford, England: Oxford University

Ridgeway, C. L., Boyle, E. H., Kuipers, K. J., \& Robinson, D. T. (1998). How do status beliefs develop? The role of resources and interactional experience. American Sociological Review, 63, 331-350.

Ridgeway, C. L., \& Correll, S. J. (2004). Unpacking the gender system: A theoretical perspective on gender beliefs and social relations. Gender \& Society, 18, 510-531.

Ridgeway, C. L., \& Erickson, K. G. (2000). Creating and spreading status beliefs. American Journal of Sociology, 106, 579-615.

Santiago, A. L. (2000). Succession experiences in Philippine family businesses. Family Business Review, 13, 15-35. 
Schröder, E., Schmitt-Rodermund, E., \& Arnaud, N. (2011). Career choice intentions of adolescents with a family business background. Family Business Review, 24, 305-321.

Schütz, A. (1972). On multiple realities. In M. Natanson (Ed.), Collected papers I: The problem of social reality (pp. 207259). Dordrecht, Netherlands: Springer.

Sharma, P., \& Irving, P. G. (2005). Four bases of family business successor commitment: Antecedents and consequences. Entrepreneurship: Theory and Practice, 29, 13-33.

Sharma, P., \& Rao, A. S. (2000). Successor attributes in Indian and Canadian family firms: A comparative study. Family Business Review, 13, 313-330.

Smith, D. E. (1987). The everyday world as problematic: A feminist sociology. Lebanon, $\mathrm{NH}$ : Northeastern University.

Sonfield, M. C., \& Lussier, R. N. (2004). First-, second-, and third-generation family firms: A comparison. Family Business Review, 17, 189-202.

Stavrou, E. (1999). Succession in family businesses: Exploring the effects of demographic factors on offspring intentions to join and take over the business. Journal of Small Business Management, 37, 43-61.

Tatoglu, E., Kula, V., \& Glaister, K. W. (2008). Succession planning in family-owned businesses: Evidence from Turkey. International Small Business Journal, 26, 155-180.

Tilly, C. (1998). Durable inequality. Berkeley: University of California.

Vera, C. F., \& Dean, M. A. (2005). An examination of the challenges daughters face in family business succession. Family Business Review, 18, 321-345.
Weber, M. (1978). The nature of social action. Cambridge, England: Cambridge University.

Weber, M. (2009). The theory of social and economic organization. New York, NY: Free Press.

Yan, J., \& Sorenson, R. (2006). The effect of Confucian values on succession in family business. Family Business Review, 19, 235-250.

Zell, E., Krizan, Z., \& Teeter, S. R. (2015). Evaluating gender similarities and differences using metasynthesis. American Psychologist, 70, 10-20.

\section{Author Biographies}

Teresa Nelson studies innovation and entrepreneurship from a strategy and organizational perspective. She integrates a focus on gender and wider diversity and inclusion themes in her scholarship, teaching and consulting from a social construction perspective. Dr. Nelson is a professor in the School of Management at Simmons College in Boston, USA.

Christina Constantinidis is a researcher in the Center for Research in Economics and Management at the University of Luxembourg. Her teaching and research focus on the areas of entrepreneurship and family business, including start-up and growth financing, networking and social capital, gender, diversity, and succession issues. Dr. Constantinidis teaches in the Master of Entrepreneurship and Innovation of the University of Luxembourg and in the Executive Degree program at HEC - University of Liege, Belgium. 